Abstracted/indexed in Academic Search Complete, Agroforestry Abstracts, Asia Journals Online, Bangladesh Journals Online, Biological Abstracts, BIOSIS Previews, CAB Abstracts, Current Abstracts, Directory of Open Access Journals, EMBASE/Excerpta Medica, Google Scholar, HINARI (WHO), International Pharmaceutical Abstracts, Open J-gate, Science Citation Index Expanded and Social Sciences Citation Index

ISSN: $1991-0088$

\title{
Synthesis of some pyrazolone derivatives from ciprofloxacin and study of their cytotoxicity
}

\author{
Hari Pado Devnath and Md. Rabiul Islam
}

Department of Chemistry, Jahangirnagar University, Savar, Dhaka 1342, Bangladesh.

\begin{tabular}{|c|c|}
\hline \multicolumn{2}{|l|}{ Article Info } \\
\hline Received: & 31 March 2010 \\
\hline Accepted: & 9 May 2010 \\
\hline Available Online: & 30 May 2010 \\
\hline \multicolumn{2}{|c|}{ DOI: 10.3329/bjp.v5i1.4693 } \\
\hline \multicolumn{2}{|c|}{$\begin{array}{l}\text { Cite this article: } \\
\text { Devnath HP, Islam MR. Synthesis of } \\
\text { some pyrazolone derivatives from } \\
\text { ciprofloxacin and study of their cyto- } \\
\text { toxicity. Bangladesh J Pharmacol. } \\
\text { 2010; 5: 30-33. }\end{array}$} \\
\hline
\end{tabular}

\begin{abstract}
Three pyrazolone derivatives with pyrazole ring extension were synthesized from ciprofloxacin by treating the parent compound with hydrazine derivatives. All the products have been characterized by IR and $1 \mathrm{H}-\mathrm{NMR}$ spectral analysis. These derivatives showed potential cytotoxicity against brine shrimp nauplii than the ciprofloxacin.
\end{abstract}

\section{Introduction}

Ciprofloxacin is a broad-spectrum fluoroquinolone antibiotic used in the treatment of a wide range of mild to moderate Gram-positive and Gram-negative infections. As ciprofloxacin, has a keto and a carboxylic acid group in the ortho position, an extra pyrazole ring system on the ciprofloxacin molecule can be created. Pyrazolone and its derivatives are used for their analgesic (Gursoy et al., 2000), anti-inflammatory (Satyanarayana and Rao, 1995), antipyretic (Manna et al., 1992), antiarrhythmic, antifungal (Bekhit and Fahmy, 2003), muscle relaxing, psychoanaleptic, anticonvulsant, enzyme inhibiting (Regan et al., 2003), antidiabetic and antibacterial activities. So, the chemistry of pyrazolone and its derivatives is particularly interesting because of their potential application in medicinal chemistry. In continuation of our work to investigate the cytotxicity (Islam et al., 2001) of pyrazolone derivatives, three pyrazolone derivatives from ciprofloxacin have been synthesized and we report herein the result of cytotoxicity.

\section{Materials and Methods}

All melting points were recorded by thin disk method on a "Fischer Johns" electro thermal melting point apparatus. Infrared spectra were recorded on DR-8001, Shimadzu FTIR spectrophotometer as a solid, which was finely grounded in a small agate mortar with a drop of nujol (liquid hydrocarbon) as a mull and also in KBr disk. ${ }^{1} \mathrm{H}-\mathrm{NMR}$ spectra were measured by WP 400 NMR spectrometer, deuterated solvents such as dimethylsulfoxide (DMSO-d6) were used as solvents and the chemical shifts were quoted as 8 -value relative to tetramethyl silane (TMS, $8=0$ ) as an internal standard. The purity of compounds was checked by TLC on silica gel plates and iodine was used as a visualizing agent.

The compound, 5-Cyclopropyl-8-fluoro-2-phenyl-7piperazin-1-yl-2,5-dihydro-pyrazolo [4,3-c]quinolin-3one, 1a (scheme 1.1) was prepared by the mixture of ciprofloxacin $(1.0238 \mathrm{~g}, 2.7229 \mathrm{mmol})$ in $10 \mathrm{~mL}$ methanol and an equivalent amount of phenyl hydrazine (0.2941 g, $2.7229 \mathrm{mmol})$ taken in $50 \mathrm{~mL}$ two necked quick fit round bottom flask, was heated in an oil bath at $120-130^{\circ} \mathrm{C}$ for 2.5 hours. The color of the reaction mixture was changed to white brown during the reflux period. The reaction mixture was allowed to cool at room temperature and was kept overnight to be 


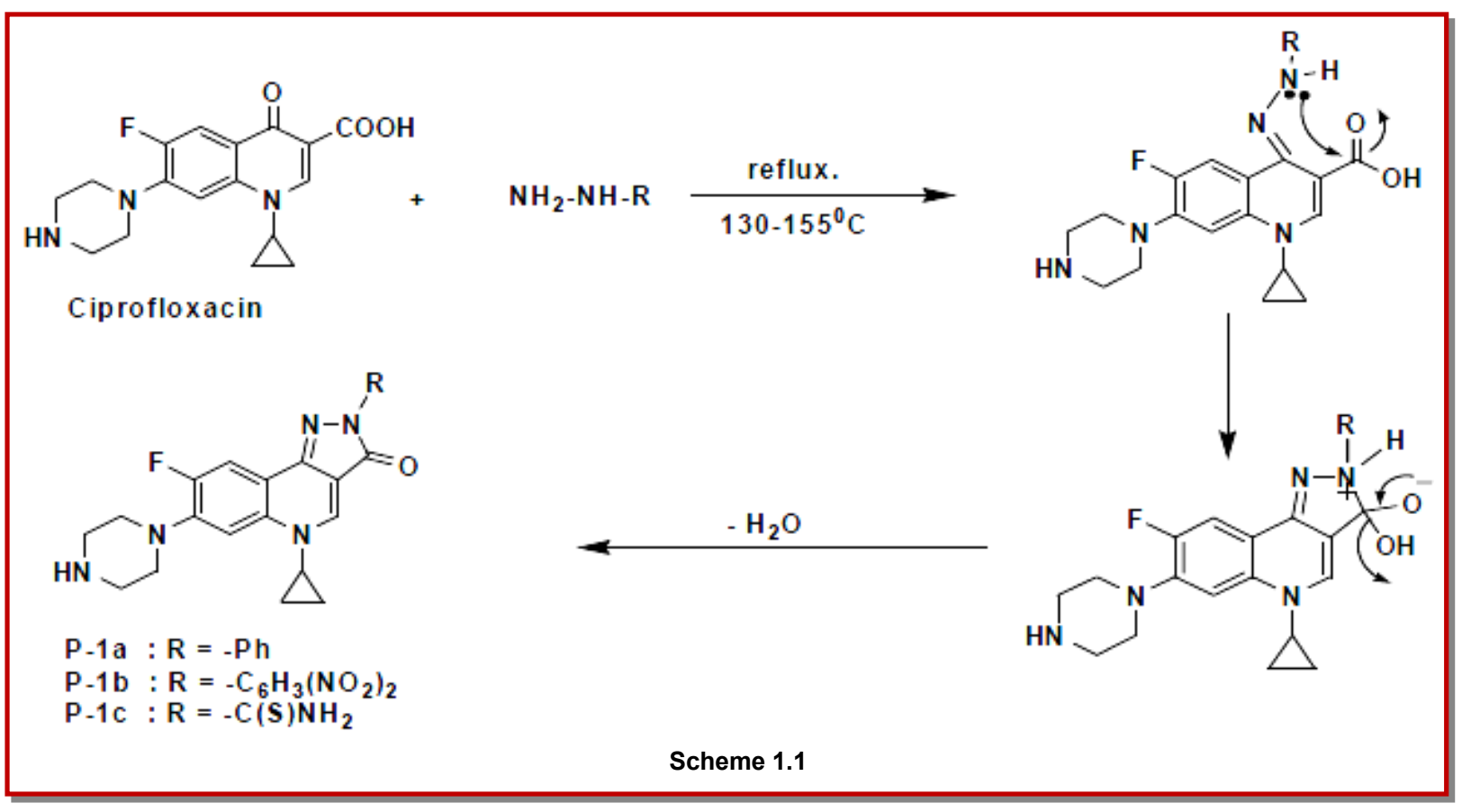<smiles></smiles>

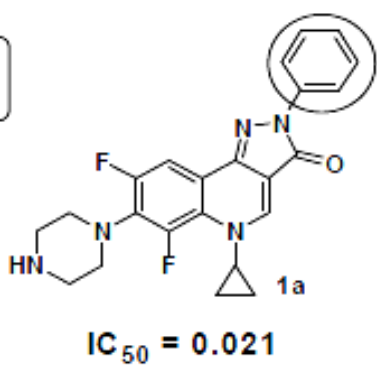

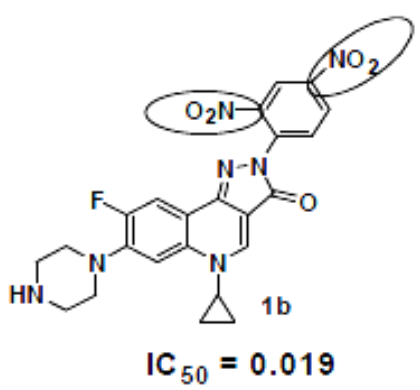

Scheme 1.2

precipitated out. Then the reaction mixture was treated with water, immediate pale yellow solid came out. The crude product was purified by recrystallization from ethanol and identified as 5-cyclopropyl-8-fluoro-2phenyl-7-piperazin-1-yl-2,5-dihydro-pyrazolo[4,3-c] quinolin-3-one, 1a. The compound 5-cyclopropyl-2-(2,4dinitro-phenyl)-8-fluoro-7-piperazin-1-yl-2,5-dihydropyrazolo[4,3-c] quinolin-3-one, 1b (scheme 1.1) was synthesized by the refluxing ciprofloxacin with phenyl hydrazine according to above process. The compound 5 -cyclopropyl-8-flouro-3-oxo-7-piperazin-1-yl-3,5dihydro-pyrazolo[4,3-c] quinoline-2-carbothioic acid amide, 1c was synthesized by the refluxing ciprofloxacin with thiosemicarbazide according to above process (scheme 1.1).

Hatching and maintenance of brine shrimp (Islam and Mohsin, 2007; Solis et al, 1993): Brine shrimps (Artemia salina) were used as test animal for the investigation of cytotoxicity. The essential condition for brine shrimp (temperature $27-30^{\circ} \mathrm{C}$, salinity $30-35 \mathrm{ppt}, \mathrm{pH} 7.5-8.5$, and strong aeration) was established by mixing sodium chloride salts in water. Natural or artificial light (at night) was required and constant oxygen supply was carried out by bubble pump machine. After obtaining the desired condition, about one teaspoon of brine shrimp eggs was added to the beaker. After 12 hours hatching aggregated brine shrimp nauplii were collected in another beaker and rinse with fresh water and applied for testing.

Preparation of test sample: $1.6 \mathrm{mg}$ of each compound in a sample vial was weighed by an analytical balance. Then $1.6 \mathrm{~mL}$ of DMSO were added to each vial and vigorously shaken to prepare stock solution. $5 \mathrm{~mL}$ of sea water was given in each test tube. With the help of micropipette specific volumes of samples were transferred from the stock solution to the test tube to get the final sample concentration of $0.05,0.1,0.15$, and $1.0 \mathrm{pg} / \mathrm{mL}$. Then 10-15 brine shrimps, immediately germinated from brine shrimp eggs, were placed in each test tube. 


\begin{tabular}{|lcccc|}
\hline \multicolumn{4}{c|}{ Table I } \\
\hline & \multicolumn{4}{c|}{ Physical data of the synthesized compounds } \\
\hline Compounds & \% of yield & Melting points $\left({ }^{\circ} \mathrm{C}\right)$ & Rf values $(\mathrm{CHCHMeOH}=9: 1)$ & Color of compounds \\
\hline $1 \mathrm{a}$ & 88 & 215 & 0.74 & White \\
$1 \mathrm{~b}$ & 82 & 203 & 0.73 & Yellow \\
$1 \mathrm{c}$ & 88 & 220 & 0.69 & White \\
\end{tabular}

Table II

Cytotoxicity activity ( $\mathrm{IC}_{50}$, after 4 hours) of synthesized compounds against brine shrimps

\begin{tabular}{|c|c|c|c|c|}
\hline Tested compounds & Concentration of sample $(\mu \mathrm{g} / \mathrm{mL})$ & $\%$ of mortality & $\mathrm{IC}_{50}($ in $\mathrm{gg} / \mathrm{mL})$ & Remarks \\
\hline \multirow[t]{4}{*}{1} & 0.1 & 63.6 & \multirow[t]{4}{*}{0.04} & \multirow[t]{4}{*}{ Moderately active } \\
\hline & 0.1 & 81.8 & & \\
\hline & 0.2 & 80.0 & & \\
\hline & 1.0 & 80.0 & & \\
\hline \multirow[t]{4}{*}{$1 \mathrm{a}$} & 0.1 & 71.4 & \multirow[t]{4}{*}{0.02} & \multirow[t]{4}{*}{ Highly active } \\
\hline & 0.1 & 76.7 & & \\
\hline & 0.2 & 78.9 & & \\
\hline & 1.0 & 80.0 & & \\
\hline \multirow[t]{4}{*}{$1 b$} & 0.1 & 81.8 & \multirow[t]{4}{*}{0.02} & \multirow[t]{4}{*}{ Very highly active } \\
\hline & 0.1 & 81.8 & & \\
\hline & 0.2 & 90.0 & & \\
\hline & 1.0 & 100.0 & & \\
\hline \multirow[t]{4}{*}{ 1c } & 0.1 & 80.0 & \multirow[t]{4}{*}{0.02} & \multirow[t]{4}{*}{ Highly active } \\
\hline & 0.1 & 88.9 & & \\
\hline & 0.2 & 88.9 & & \\
\hline & 1.0 & 100.0 & & \\
\hline
\end{tabular}

Counting of nauplii: After 1, 2, 3 and 4 hours, the test tubes were observed and the number of survived nauplii in each test tube was counted and results were noted. The percentage of mortality of brine shrimp was calculated for each sample that gives different mortality for different concentrations. An approximate linear correlation was observed when logarithm of concentration was plotted against percentage of mortality and the values of $\mathrm{IC}_{50}$ were calculated for each sample. The $\mathrm{IC}_{50}$ represents the concentration of a compound, which will kill, or inactive 50 percent of the test animal. $\mathrm{IC}_{50}$ is inversely proportional to the toxicity of a compound, i.e. the lower the $\mathrm{IC}_{50}$ the higher the toxicity.

\section{Results}

Physical constants give the preliminary idea about the formation of new compounds (Table I). The resulting spectral data analyses of synthesized compounds:

Compound 1a: IR (vmax, $\left.\mathrm{KBr}, \mathrm{cm}^{-1}\right): 3200.6 \mathrm{~cm}^{-1}(\mathrm{~s}$, sh, $\mathrm{VN}-\mathrm{H}) ; 3070 \mathrm{~cm}^{-1}\left(\mathrm{~s}, \mathrm{sh}, \mathrm{VC}-\mathrm{H}\right.$, aromatic); $920 \mathrm{~cm}^{-1}(\mathrm{~s}, \mathrm{sh}$, VC-H, aromatic, out of plane); $2961 \mathrm{~cm}^{-1}(\mathrm{w}, \mathrm{sh}, \mathrm{VC}-\mathrm{H}$ $\mathrm{CH} 2) ; 1447.5$ and $1378 \mathrm{~cm}^{-1}\left(\mathrm{~s}, \mathrm{sh}, \mathrm{v}_{\mathrm{C}-\mathrm{H}}\right.$ bending, $\left.\mathrm{CH}_{2}\right)$; 1612 and $1490 \mathrm{~cm}^{-1}$ (s, sh, vc-c, aromatic); $1604 \mathrm{~cm}^{-1}$ (s, sh, $\mathrm{VC}-\mathrm{N}) ; 1700 \mathrm{~cm}^{-1}\left(\mathrm{~s}, \mathrm{sh}, \mathrm{VC}=\mathrm{O}\right.$, lactam), $1576 \mathrm{~cm}^{-1}(\mathrm{~s}, \mathrm{sh}, \mathrm{VN}$ $-\mathrm{H}$, bending); $1652 \mathrm{~cm}^{-1}(\mathrm{~m}, \mathrm{VC}=\mathrm{C}$, alkene $) ; 1028 \mathrm{~cm}^{-1}(\mathrm{~s}$, sh, vc- N amine); $858 \mathrm{~cm}^{-1}$ (s, br., VN-H, wagging); $752 \mathrm{~cm}$ ${ }^{-1}(\mathrm{~s}, \mathrm{sh}, \mathrm{VC}-\mathrm{F})$ ). 1HNMR (400 MHz, DMSO-d6): 80.866 (m, 4H, - CH2, cyclopropane); $1.523(\mathrm{t}, 1 \mathrm{H},-\mathrm{CH}) ; 2.53$ (m, 4H, - cH2); 3.48 (d, 4H, -cH2); 15.251 (s, 1H, -NH); $4.562(\mathrm{~d}, 1 \mathrm{H},=\mathrm{CH}) ; 7.58(\mathrm{~m}, 5 \mathrm{H}$, aromatic); $8.407(\mathrm{~d}, 1 \mathrm{H}$, aromatic); 8.67 (s, 1H aromatic).

Compound 1b: IR ( $\left.\mathrm{V}_{\max }, \mathrm{KBr}, \mathrm{cm}^{-1}\right): 3296 \mathrm{~cm}^{-1}(\mathrm{~s}, \mathrm{sh}, \mathrm{VN}-$ $\mathrm{H}) ; 3025 \mathrm{~cm}^{-1}$ (s, sh, VC-H, aromatic); $825.5 \mathrm{~cm}^{-1}$ (s, sh, VC$\mathrm{H}$, aromatic, out of plane); $2856 \mathrm{~cm}^{-1}(\mathrm{w}, \mathrm{sh}, \mathrm{VC}-\mathrm{H}, \mathrm{CH} 2)$; 1447.5 and $1378 \mathrm{~cm}^{-1}(\mathrm{~s}, \mathrm{sh}, \mathrm{VC}-\mathrm{H}$ bending, CH2); 1549.7 and $1358.8 \mathrm{~cm}^{-1}(\mathrm{~m}, \mathrm{VN}=\mathrm{O}, \mathrm{Nitro}) ; 1612$ and $1490 \mathrm{~cm}^{-1}(\mathrm{~s}$, 
sh, $\mathrm{v}_{\mathrm{C}}={ }_{\mathrm{C}}$, aromatic); $1723 \mathrm{~cm}^{-1}\left(\mathrm{~s}, \mathrm{sh}, \mathrm{v}_{\mathrm{C}}=_{\mathrm{N}}\right) ; 1627 \mathrm{~cm}^{-1}$ (s, sh, $\mathrm{VC}=\mathrm{O}$, lactam), $1576 \mathrm{~cm}^{-1}(\mathrm{~s}, \mathrm{sh}, \mathrm{VN}-\mathrm{H}$, bending); $1652 \mathrm{~cm}^{-1}\left(\mathrm{~m}, \mathrm{VC}=\mathrm{C}\right.$, alkene); $1028 \mathrm{~cm}^{-1}(\mathrm{~s}, \mathrm{sh}, \mathrm{VC}-\mathrm{N}$ amine); $825 \mathrm{~cm}^{-1}\left(\mathrm{~s}\right.$, br., $\mathrm{v}_{\mathrm{N}-\mathrm{H}}$, wagging); $744 \mathrm{~cm}^{-1}\left(\mathrm{~s}\right.$, sh, $\mathrm{v}_{\mathrm{C}}$ F). ${ }^{1} \mathrm{HNMR} \quad(400 \mathrm{MHz}$, DMSO-d6): $80.856 \quad(\mathrm{~m}$, cyclopropane); $1.234(\mathrm{t}, 1 \mathrm{H},-\mathrm{CH}) ; 2.50(\mathrm{~m}, 4 \mathrm{H},-\mathrm{CH} 2)$; 3.430 (t, 4H, -CH2); 15.211 (s, 1H, $-\mathrm{NH}) ; 4.563$ (d, 1H, $=\mathrm{CH}) ; 7.550$ (dd, Hb); 7.959 (d, Ha); 7.268 (d, Hc); 8.672 (s, Hd aromatic); 8.325 (d, He aromatic).

Compound 1c: IR (vmax, $\left.\mathrm{KBr}, \mathrm{cm}^{-1}\right): 3373 \mathrm{~cm}^{-1}(\mathrm{~s}, \mathrm{sh}, \mathrm{VN}-$ $\mathrm{H}) ; 3184 \mathrm{~cm}^{-1}\left(\mathrm{~s}\right.$, sh, $\mathrm{v}_{\mathrm{C}-\mathrm{H}}$, aromatic); $824.5 \mathrm{~cm}^{-1}\left(\mathrm{~s}\right.$, sh, $\mathrm{v}_{\mathrm{C}-\mathrm{H}}$, aromatic, out of plane); $2972 \mathrm{~cm}^{-1}(\mathrm{w}, \mathrm{sh}, \mathrm{VC}-\mathrm{H}, \mathrm{CH} 2)$; 1452 and $1374 \mathrm{~cm}^{-1}(\mathrm{~s}, \mathrm{sh}, \mathrm{VC}-\mathrm{H}$ bending, $\mathrm{CH} 2) ; 1576$ and $1490 \mathrm{~cm}^{-1}\left(\mathrm{~s}, \mathrm{sh}, \mathrm{VC}=\mathrm{C}\right.$, aromatic); $1683 \mathrm{~cm}^{-1}(\mathrm{~s}, \mathrm{sh}, \mathrm{VC}=\mathrm{N})$; $1616 \mathrm{~cm}^{-1}\left(\mathrm{~s}, \mathrm{sh}, \mathrm{VC}=\mathrm{O}\right.$, lactam), $1576 \mathrm{~cm}^{-1}(\mathrm{~s}, \mathrm{sh}, \mathrm{VN}-\mathrm{H}$, bending); $1653 \mathrm{~cm}^{-1}\left(\mathrm{~m}, \mathrm{VC}=\mathrm{C}\right.$, alkene); $1024 \mathrm{~cm}^{-1}(\mathrm{~s}$, sh, VC-N amine); $1292 \mathrm{~cm}^{-1}$ (s, sh, VC=s), $825 \mathrm{~cm}^{-1}$ (s, br., VN$\mathrm{H}$, wagging); $730 \mathrm{~cm}^{-1}(\mathrm{~s}$, sh, VC-F ); $1 \mathrm{HNMR}(400 \mathrm{MHz}$, DMSO-db): 80.858 (m, 4H, -CH2, cyclopropane); 1.432 $(\mathrm{t}, 1 \mathrm{H},-\mathrm{CH}) ; 2.55(\mathrm{~m}, 4 \mathrm{H},-\mathrm{CH} 2) ; 3.45(\mathrm{t}, 4 \mathrm{H},-\mathrm{CH} 2)$; 15.205 (s, 1H, -NH); $4.56(\mathrm{~d}, 1 \mathrm{H},=\mathrm{CH}) ; 4.305$ (s, 2H, $\mathrm{NH} 2) ; 8.502$ (d, 1H, aromatic); 8.60 (s, 1H aromatic).

\section{Discussion}

In the present work, the synthesized compounds were investigated for their property as biologically active agents by brine shrimp lethality bioassay. Among them the compounds $\mathbf{1 b}$ are very highly active. $\mathbf{1 a}$ and $\mathbf{1 c}$ are highly active but ciprofloxacin is moderately active.

The chemical structure of a drug is important as the relatively minor modification in the drug molecule may results a major change in pharmacological properties.

The synthesized compounds $\mathbf{1 a}, \mathbf{1} \mathbf{b}$ and $\mathbf{1 c}$ show better bio-activity property which provide that pyrazolone derivatives of ciprofloxacin may be very important in producing anti-cancer activity. The substituted benzene ring by $-\mathrm{NO}_{2}$ group of the 5-cydopropyl-2-(2,4-dinitrophenyl)-8-fluoro-7-pperazin-1-yl-2,5-dihydro-pyrazolo [4,3-c] quinolin-3-one, $\mathbf{1 b}$ show better activity than unsubstituted benzene. The increasing order of the activity from our research work of the synthesized compounds is $1<1 \mathrm{c}<1 \mathrm{a}<1 \mathrm{~b}$ (Scheme 1.2).

\section{Acknowledgement}

The authors express their sincere thanks to Md. Lokman Hossain, Okayoma University, Japan for supplying the ${ }^{1} \mathrm{H}$ NMR spectra of the synthesized compounds.

\section{References}

Bekhit AA, Fahmy HT. Design and synthesis of some substituted ${ }^{1} \mathrm{H}$-pyrazolyl-oxazolidines or ${ }^{1} \mathrm{H}$-pyrazolyl-thiazolidines as anti-inflammatory-antimicrobial agents. Arch Pharm (Weinheim). 2003; 336: 111-18.

Gursoy A, Demirayak S, Capan G, Erol K, Vural K. Synthesis and preliminary evaluation of new 5-pyrazolinone derivatives as analgesic agents. Eur J Med Chem. 2000; 35: 359-64.

Islam MR, Khayer K, Ahmad MM. Synthesis of 3- methylpyrazoline-5-one and its 3,3-dimethyl-5,5-ethene-bis2-pyrazoline-4,4-dione, substituted cyclic tri-azothione and N-acetylated derivatives. J Bangladesh Chem Soc. 2001; 14: 33.

Islam MR, Mohsin M. Synthesis of isatin, 5-chloroisatin and their $\Delta^{2}-1,3,4$-oxadiazoline derivatives for comparative cytotoxicity study on brine shrimp. Bangladesh J Pharmacol. 2007; 2: 7-12.

Manna F, Chimenti F, Bolasco A, Cenicola ML, D'Amico M, Parrillo C, Rossi F, Marmo E. Anti-inflammatory, analgesic and antipyretic N-acetyl- $\Delta^{2}$-pyrazolines and dihydrothienocoumarines. Eur J Med Chem. 1992; 27: 633-39.

Solis PN, Wright CW, Anderson MM, Gupta MP, Phillipson JD. A microwell cytotoxicity assay using Artemia salina (brine shrimp). Planta Med. 1993; 59: 250-52.

Regan J, Capolino A, Cirillo PF, Gilmore T, Graham AG, Hickey E, Kroe RR, Madwed J, Moriak M, Nelson R, Pargellis CA, Swinamer A, Torcellini C, Tsang M, Moss N. Structure activity relationships of the p38alpha MAP kinase inhibitor 1-(5-tert-butyl-2-p-tolyl-2H-pyrazol-3yl)-3-[4-(2morpholin-4-yl-ethoxy) maphthalen-1-yl]urea (BIRB 796). J Med Chem. 2003; 46: 4676-86.

Satyanarayana K, Rao MNA. Synthesis of 4-[5-(substituted aryl)-4,5-dihydro-1H-pyrazol-3-yl]-3-phenyl-sydnones as anti-inflammatory, antiarthritic and analgesic agents. Eur J Med Chem. 1995; 30: 641-45. 